\title{
DECENTRALIZACJA JAKO USTROJOWA ZASADA RELACJI POMIĘDZY ORGANAMI WŁADZY PUBLICZNEJ
}

\section{KONSTYTUCYJNE PODSTAWY DECENTRALIZACJI WLADZY PUBLICZNEJ}

Wieloaspektowy charakter stosunków społeczno-gospodarczych, skutkujacy ustawowym formułowaniem złożonych zadań publicznych, powoduje, że podmioty władzy publicznej wchodzą w skomplikowane wzajemne relacje. Wymaga to normatywnego uporządkowania, odpowiedniej struktury organizacyjnej i organizacji działania. Ich modelowanie przyczyniać się ma do zapewnienia skuteczności i efektywności wykonywania zadań publicznych ${ }^{1}$.

Złożone zadania publiczne wymagają kompleksowych regulacji normatywnych, umiejscowienia aktywności podmiotów władzy publicznej w całokształcie sytemu prawa, z poszanowaniem podstawowych zasad konstytucyjnych określających ustrój gospodarczy i polityczny państwa. Jest to szczególnie trudne, gdy ustawowo określona powinność publiczna ${ }^{2}$ realizowana jest na każdym poziomie sprawowania władzy publicznej, w różnych układach terytorialnych.

Dla budowania odpowiednich relacji pomiędzy organami władzy publicznej w tych obszarach, w których występują silne powiązania w gospodarcze, społeczne i kulturowe, konieczne jest ukształtowanie odpowiednich powiązań normatywnych, uwzględniajacych zasadnicze ramy ustrojowe, strukturalne

\footnotetext{
${ }^{1}$ Kryteria skuteczności i efektywności działania organów administracji publicznej stanowią wynik wdrażania koncepcji dobrego zarządzania sferą publiczna, która odnosi się do zasad i procesów wpływających na wykonywanie zadań publicznych. Zob. m.in.: M. Debbasch, J. M. Pointer, Administracja i zarzqdzanie, w: J. Łętowski (red.), Administracja Republiki Francuskiej, Warszawa 1984, s. 73 i n.; J. Skrzydło-Niżnik, K. Sieniawska, Prawne i pozaprawne uwarunkowania sprawności (efektywności) działania administracji publicznej, w: Instytucje wspótczesnego prawa administracyjnego. Księga jubileuszowa Prof. J. Filipka, Kraków 2001, s. 517 i n.; J. Szreniawski, Wstęp do nauki administracji, Lublin 2004, s. 48 i n.; I. Lipowicz, Europeizacja administracji publicznej, „Ruch Prawniczy, Ekonomiczny i Socjologiczny” 70, 2008, z. 1, s. 5-17.

${ }^{2}$ Zob. T. Rabska, Norma zadaniowa w świetle publicznego prawa gospodarczego, w: A. Choduń, S. Czepita (red.), Poszukiwaniu dobra wspólnego. Ksiega jubileuszowa Profesora Macieja Zielińskiego, Szczecin 2010.
} 
i funkcjonalne administracji publicznej rządowej i samorządowej określone w Konstytucji $\mathrm{RP}^{3}$, która zapewnia decentralizację władzy publicznej ${ }^{4}$.

Decentralizacja traktowana jako ustrojowoprawna konstrukcja stosunków między podmiotami prawa publicznego, wyznacza organizację władzy wykonawczej. Z konstytucyjnej zasady decentralizacji, interpretowanej w powiązaniu z pozostałymi zasadami ustrojowymi, a w szczególności z zasada pomocniczości - wynika obowiązek tworzenia określonych układów zadań i kompetencji, który sprowadza się do formuły „przekazywania z góry w dół” zadań publicznych na niższe ogniwa ich wykonywania ${ }^{5}$. W kontekście analizowanych zagadnień strukturalnych aparatu państwa powinna być interpretowana jako zasada nakazująca budowanie struktur oddolnie, a jej przestrzeganie widoczne powinno być w rozwiąaniach instytucjonalno-organizacyjnych.

Obowiazywanie zasady decentralizacji władzy publicznej to respektowanie terytorialnych wspólnot samorządowych. Samorząd terytorialny stanowi integralną część ustroju państwa, z konstytucyjnie gwarantowaną samodzielnościa jednostek samorządu terytorialnego, jako podmiotów prawa i zdecentralizowanych podmiotów władzy publicznej. Jest wyrazem nowoczesnego podejścia do zarządzania publicznego ${ }^{6}$, elementem nowoczesnej organizacji i funkcjonowania państwa o zdecentralizowanej strukturze, której nie można pomijać w kształtowaniu nowoczesnych struktur organizacji działań. To przepis art. 16 ust. 2 Konstytucji RP w brzmieniu: „Samorząd terytorialny uczestniczy w sprawowaniu władzy publicznej. Przysługująca mu w ramach ustaw istotna część zadań publicznych samorząd wykonuje w imieniu własnym i na własną odpowiedzialność", czyni samorząd terytorialny współodpowiedzialnym za funkcjonowanie państwa, stanowiąc jednocześnie podstawy współpracy organów władzy wykonawczej - aparatu centralnego i zdecentralizowanych struktur samorządowych.

${ }^{3}$ Konstytucja Rzeczypospolitej Polskiej z 7 kwietnia 1997 r., Dz. U. 1997, Nr 78, poz. 483; zm.: Dz. U. 2001, Nr 28, poz. 319; Dz. U. 2000, Nr 200, poz. 1471; Dz. U. 2009, Nr 114, poz. 946 (dalej jako: Konstytucja RP).

4 Art. 15 Konstytucji RP.

${ }_{5}$ Zob m.in. na ten temat: Z. Zgud, Zasada subsydiarności w prawie europejskim, Kraków 1999; A. Szpor, Państwo a subsydiarność jako zasada prawa $w$ UE $i w$ Polsce, „Samorząd Terytorialny” 2001, nr 1-2, s. 20; Z. Cieślik, Zagadnienia prawa europejskiego. Informacje na temat kontroli działań podejmowanych przez UE pod względem zgodności z zasada subsydiarności, „Zeszyty Prawnicze Biura Studiów i Ekspertyz" 2004, nr 3, s. 33; E. Popławska, Zasada pomocniczości (subsydiarności), w: W. Sokolewicz (red.), Zasady podstawowe polskiej konstytucji, Warszawa 1998, s. 190; E. Przybylska-Marciniuk, Zasada subsydiarności w projekcie Traktatu konstytucyjnego, w: Przyszły traktat konstytucyjny. Zasadnicze zmiany ustrojowe w Unii Europejskiej, t. 2, Warszawa 2004.

${ }^{6}$ M. Kulesza podkreśla: „[...] samorząd i decentralizacja stanowią podstawę samodzielnego zarządzania sprawami publicznymi przede wszystkim w rozumieniu gospodarczym, w systemie sieciowym, a nie hierarchicznym, przez osiaganie korzyści społecznych i gospodarczych w skali lokalnej czy regionalnej, poprzez działanie na rzecz rozwoju danej jednostki samorządu terytorialnego, organizowanie dostarczania usług publicznych, współdziałanie i zarazem konkurowanie z innymi samorządami, udział w rynkach ponadlokalnych i ponadregionalnych itp. [...]” (idem, O tym, ile jest decentralizacji w centralizacji, a także o osobliwych nawykach uczonych administratywistów, w: J. Supernat (red.), Między tradycja a przyszłościa w nauce prawa administracyjnego. Księga jubileuszowa dedykowana Profesorowi Janowi Bociowi, Wrocław 2009, s. 415). 
Samorząd terytorialny jest przejawem demokratyzacji życia społecznego $^{7}$, a o jego doniosłości świadczy zakres spraw publicznych, które moga być wykonywane przez jednostki samorządu terytorialnego ${ }^{8}$. Ta społeczna problematyka samorządu terytorialnego nabiera obecnie szczególnego znaczenia. Podkreśla się, że nie każdy rodzaj samorządu ma dla demokratyzacji jednakowe znaczenie. Sposób organizacji administracji oparty na decentralizacji jest „[...] wówczas istotny społecznie, gdy sfera zdecentralizowanej tą droga administracji dotyczy istotnych zagadnień społecznych"9. Oznacza to, że o istocie samorządu terytorialnego decydują także zakres i charakter (doniosłość) wykonywanych zadań publicznych.

\section{ZASADA DECENTRALIZACJI W PROWADZENIU POLITYKI ROZWOJU}

Przykładem takiego całościowego, szczególnego, odrębnego działu zadań państwa, normatywnie wyodrębnionej dziedziny aktywności podmiotów władzy publicznej, obejmującego wszystkie poziomy sprawowania władzy publicznej-jest obszar prowadzenia polityki rozwoju ${ }^{10}$. Prowadzenie polityki rozwoju obejmuje zadania publiczne realizowane w skali ogólnokrajowej, a równolegle w wymiarze regionalnym i lokalnym, tworząc ścisłe związki pomiędzy podmiotami aparatu władzy wykonawczej państwa, zobowiązanego do osiagnięcia wyznaczonego ustawowo celu, jakim jest zapewnienie trwałego i zrównoważonego rozwoju kraju, spójności społeczno-gospodarczej, regionalnej i przestrzennej, podnoszenie konkurencyjności gospodarki oraz tworzenie nowych miejsc pracy w skali krajowej, regionalnej lub lokalnej ${ }^{11}$.

Cel publiczny tak szeroko, normatywnie określony ustawą z 6 grudnia 2006 r. o zasadach prowadzenia polityki rozwoju, a także zakres zaangażo-

\footnotetext{
${ }^{7} \mathrm{Na}$ ten temat: J. Jeżewski, Idea demokracji w przeksztatceniach samorzqdu terytorialnego, „Ruch Prawniczy, Ekonomiczny i Socjologiczny” 77, 2015, z. 3 (Polska - 25 lat samorządu terytorialnego), s. 65-78.

${ }^{8}$ Trybunał Konstytucyjny podkreśla: „Pojęcie decentralizacji oznacza proces stałego poszerzania uprawnień jednostek władzy publicznej niższego stopnia w drodze przekazywania im zadań, kompetencji oraz niezbędnych środków. Decentralizacja, o której mówi Konstytucja Rzeczypospolitej Polskiej, nie jest jednorazowym przedsięwzięciem organizacyjnym, lecz trwała cecha kultury politycznej państwa zbudowanej na właściwych rozwiązaniach ustawowych, zgodnych z konstytucyjnymi zasadami ustroju Rzeczypospolitej”; Orzeczenie TK, K 24/02, OTK -A, 2003, nr 2, poz. 11.

${ }_{9}^{9} \mathrm{Na}$ temat decentralizacji prawnej zob.: J. Starościak, Decentralizacja administracji, Warszawa 1960, s. 14.

${ }_{10}$ Wprowadzonej ustawa z 6 grudnia 2006 r. o zasadach prowadzenia polityki rozwoju, Dz. U. 2006, Nr 227, poz. 1658; zm.: Dz. U. 2007, Nr 140, poz. 984; Dz. U. 2008, Nr 216, poz. 1370; Dz. U. 2009, Nr 19, poz. 100; t.jedn.: Dz. U. 2009, Nr 84, poz.712; zm.: Dz. U. 2009, Nr 157, poz. 1241; Dz. U. 2011, Nr 279; poz. 1644, Dz. U. 2013, poz. 714; t.jedn.: Dz. U. 2014, poz. 1649, Dz. U. 2015, poz. 349, poz. 1240, 1358, 1890 (dalej jako: u.z.p.p.r.).

${ }^{11}$ Art. 2 u.z.p.p.r.
} 
wanych podmiotów zobowiązanych do jego osiagnięcia ${ }^{12}$ skutkuja powstaniem złożonych, wielopoziomowych relacji, zachodzących na różnych płaszczyznach współdziałania pomiędzy podmiotami prowadzenia polityki rozwoju: Radą Ministrów a jednostkami samorządu terytorialnego ${ }^{13}$. Poza szczególnym układem podmiotów prowadzenia polityki rozwoju - Radą Ministrów i samorządem województwa, samorządem powiatowm i samorządem gminnym - także specyfikę celu aktywności organów administracji publicznej, określonej jako działania na rzecz spójności i rozwoju, prowadzone w skali krajowej, regionalnej i lokalnej.

Ustawa o zasadach prowadzenia polityki rozwoju reguluje całkowicie nowa problematyke prawna, dotyczy zupełnie nowych zadań o fundamentalnym znaczeniu również dla innych sfer aktywności organów władzy publicznej (dziedzin odnoszacych się do rozwoju kraju i spójności w każdym jej ustawowo określonym wymiarze). Jednocześnie odnosi się do ustroju państwa - struktury władzy wykonawczej. Wprowadza prawne rozumienie polityki rozwoju, jako „zespołu wzajemnie powiązanych działań, opierające się na ustawowym założeniu, jakim jest wieloszczeblowość jej prowadzenia. Ustawa ta, wpisując się w całokształt działań państwa na rzecz spójności i rozwoju jednostki samorządu terytorialnego - podkreśla znaczenie zdecentralizowanych struktur samorządowych. Do realizacji powinności publicznej prowadzenia polityki rozwoju u.z.p.p.r. wykorzystuje układ organizacyjny określony w Konstytucji RP, tym samym realizuje nadrzędna zasadę ustrojową decentralizacji władzy publicznej oraz podstawowa wartość, jaka jest w tym przypadku samodzielność jednostek samorządu terytorialnego.

\section{PRAWNA KONCEPCJA PROWADZENIA POLITYKI ROZWOJU JAKO ZESPOLU WZAJEMNIE POWIĄZANYCH DZIAŁAŃ}

Charakterystyczny dla tej dziedziny aktywności podmiotów władzy wykonawczej jest sposób podejmowanych i realizowanych działań. Wyznaczony on został po raz pierwszy w ustawodawstwie jako „zespół wzajemnie powiązanych działań” i służy wzmocnieniu normatywnie określonego obowiązku współpracy podmiotów prowadzenia polityki rozwoju ${ }^{14}$. Ustawodawca zadecydował, że podejmowanie działań w tym obszarze wymaga współpracy na wszystkich poziomach sprawowania władzy wykonawczej, a ze względu na wspólny zakres ich działania współpraca ta musi być prowadzona w szczególnym trybie wyrażonym ustawową formułą „zespołu wzajemnie powiązanych działań”.

Przyjęta ustawowa konstrukcja prowadzenia polityki rozwoju jako zespołu powiązanych działań wynika zarówno z charakteru zadań publicznych, jak

${ }^{12}$ Nowelą z 2015 r. do katalogu podmiotów prowadzenia polityki rozwoju dodano związki metropolitalne.

${ }^{13}$ K. Kokocińska, Prawny mechanizm prowadzenia polityki rozwoju $w$ zdecentralizowanych strukturach władzy publicznej, Poznań 2014.

${ }^{14}$ Art. 2 u.z.p.p.r. w związku z brzmieniem art. 1 u.z.z.p.r. 
i szeroko określonego celu publicznego osiaganego w skali krajowej, regionalnej i lokalnej. Są to działania ogólnosystemowe, realizowane na każdym poziomie podziału terytorialnego państwa i przez wszystkie podmioty władzy wykonawczej, zatem wymagające współpracy.

To szczególne, normatywne ujęcie powinności publicznej - od strony podmiotowej i przedmiotowej - powoduje konieczność traktowania administracji publicznej jako zintegrowanej całości w sensie funkcjonalnym, ze względu na charakter powierzonej jej powinności publicznej i skalę podejmowanych działań. Prowadzenie polityki rozwoju przez Radę Ministrów, samorząd województwa oraz samorząd powiatowy i gminny determinuje charakter wzajemnych, ścisłych związków podmiotów władzy wykonawczej. Współpraca podmiotów prowadzenia polityki oparta na wzajemnie powiązanych działaniach dotyczy samodzielnych, niezależnych podmiotów publicznych. Równorzędność stron współdziałania stanowi istotną właściwość analizowanych działań powiązanych i implikuje przyjęte rozwiązania normatywne w płaszczyźnie współpracy.

Ustrojowa pozycja podmiotów prowadzenia polityki rozwoju determinuje sposób ujęcia ich współpracy, który powinien zapewnić spójność działań podejmowanych przez Radę Ministrów, samorząd województwa oraz samorząd powiatowy i gminny, a także pomiędzy jednostkami samorządu terytorialnego. Oznacza to spójność celów i kierunków regionalnych działań samorządu województwa na rzecz rozwoju regionu z krajową polityką rozwoju Rady Ministrów, a jednocześnie uwzględnianie przez Radę Ministrów w polityce ogólnokrajowej ujęcia terytorialnego. Obowiązek osiagania spójności działań podejmowanych przez jednostki samorządu terytorialnego wyznacza także relacje polityki rozwoju samorządu województwa do polityk samorządowych struktur lokalnych ${ }^{15}$.

Ten sposób ujęcia osiagania wspólnego dla podmiotów prowadzenia polityki rozwoju celu wymaga zupełnie nowych form współdziałania. Istotny jest także sposób jego zorganizowania w sferze prowadzenia polityki rozwoju od strony proceduralnej.

Samodzielności podmiotów prowadzenia polityki rozwoju wpływa na dobór prawnych form współdziałania. Dodatkowo o ich konstrukcji przesądza normatywnie określony tryb działań, jako wzajemnie powiązanych. Są to zróżnicowane pod względem charakteru prawnego formy współdziałania właściwe dla określonego typu relacji publicznoprawnych, o różnym stopniu związania. Przede wszystkim, co należy podkreślić, ustawodawca zrezygnował z władczych form działania ${ }^{16}$. Wprowadzona została kompleksowa regulacja w zakresie programowania polityki (opartego na współdziałaniu typu: działania w uzgodnieniu, konsultacje, opiniowanie), którego efektem powinien być spójny system dokumentów strategicznego programowania - strategii rozwo-

15 K. Kokocińska, op. cit., s. 197 i n., i cytowana tam literatura.

${ }_{16}$ W tym obszarze współpracy ustawodawca pozostawił podmiotom dużą samodzielność doboru form działania, w szczególności w sferze współpracy przy wykonywaniu działań materialno-technicznych lub społeczno-organizatorskich. 
ju ${ }^{17}$ i programów ${ }^{18}$ oraz dokumentów programowych ${ }^{19}$ - opracowywanych we współpracy i przyjmowanych na każdym poziomie sprawowania władzy publicznej ${ }^{20}$.

Aby wyznaczyć relacje pomiędzy podmiotami prowadzenia polityki rozwoju na etapie jej realizacji, ustawodawca wprowadził szczególny, dotychczas niestosowany tryb współdziałania opartego na stosunkach dwustronnych - szczególny rodzaj kontraktów zawieranych pomiędzy organami władzy wykonawczej. Określić je można jako konsensualne akty ze sfery prawa publicznego. Są to: (1) umowa partnerstwa ${ }^{21}$ zawierana pomiędzy państwem członkowskim a Komisją Europejska, której treść ustalana jest we współpracy Rady Ministrów z jednostkami samorządu terytorialnego oraz partnerami społecznymi i gospodarczymi, oraz (2) kontrakt terytorialny ${ }^{22}$ - umowa negocjowana pomiędzy Radą Ministrów a samorządem województwa (przy udziale jednostek samorządu powiatowego i gminnego). Konstrukcja tych aktów jest szczególna; wprowadzono ją wyłącznie na potrzeby związane z realizacją zadań publicznych w sferze prowadzenia polityki rozwoju. Ustawodawca przyją, że dla ułożenia relacji opartych na współdziałaniu niezależnych podmiotów i dla skuteczności ich działań najbardziej adekwatnym do tych stosunków, a jedno-

17 Art. 9 u.z.p.p.r. stanowi, że strategiami rozwoju są: 1) długookresowa strategia rozwoju kraju - dokument określający główne cele, wyzwania i kierunki rozwoju społeczno-gospodarczego kraju, z uwzględnieniem zasady zrównoważonego rozwoju, obejmujący okres co najmniej 15 lat; 2) średniookresowa strategia rozwoju kraju - dokument określajacy podstawowe uwarunkowania, cele i kierunki rozwoju kraju w wymiarze społecznym, gospodarczym, regionalnym i przestrzennym, obejmujacy okres 4-10 lat, realizowany przez strategie rozwoju oraz przy pomocy programów, z uwzględnieniem okresu programowania Unii Europejskiej; 3) inne strategie rozwoju - dokumenty określające podstawowe uwarunkowania, cele i kierunki rozwoju odnoszące się do sektorów, dziedzin, regionów lub rozwoju przestrzennego, w tym obszarów metropolitalnych i obszarów funkcjonalnych.

${ }_{18}$ Zgodnie z brzmieniem przepisu art. 15. ust. 1 u.z.p.p.r. programy sa dokumentami o charakterze operacyjno-wdrożeniowym ustanawianymi w celu realizacji średniookresowej strategii rozwoju kraju oraz strategii rozwoju, o których mowa w art. 9 pkt 3, określającymi działania przewidziane do realizacji zgodnie z ustalonym systemem finansowania i realizacji, stanowiacym element programu. Programy przyjmuje się w drodze uchwały lub decyzji odpowiedniego organu.

19 Są to umowa partnerstwa oraz programy służące jej realizacji (art. 5 pkt 1a u.z.p.p.r.).

${ }^{20} \mathrm{Na}$ temat charakteru prawnego aktów programowania polityki rozwoju zob. m.in.: wyrok TK z 12 grudnia 2011 r., P 1/11; a także: K. Kokocińska, Opinia prawna na temat rzadowego projektu ustawy o zmianie niektórych ustaw w zwiazku z wdrażaniem funduszy strukturalnych $i$ Funduszu Spójności (druk numer 950) z 14 października 2008 r.; eadem, Wybrane formy prowadzenia polityki rozwoju, w: B. Popowska, K. Kokocińska (red.), Instrumenty i formy prawne dziatania administracji gospodarczej, Poznań 2009; eadem, Prawny mechanizm..., s. 148-157 i cytowana tam literatura.

${ }^{21}$ Przepis art. 5 pkt 9 a) u.z.p.p.r. definiuje umowę partnerstwa jako umowę określającą uwarunkowania, cele i kierunki wykorzystania środków pochodzących z budżetu Unii Europejskiej, przygotowaną z udziałem partnerów społecznych i gospodarczych oraz zatwierdzoną przez Komisję Europejską.

${ }_{22}$ Zgodnie z brzmieniem przepisu art. 5 pkt 4 c) u.z.p.p.r. kontrakt terytorialny oznacza umowę określającą cele i przedsięwzięcia priorytetowe, które mają istotne znaczenie dla rozwoju kraju oraz wskazanego w niej województwa, sposób ich finansowania, koordynacji i realizacji, a także dofinansowanie, opracowywanych przez zarząd województwa, programów służących realizacji umowy partnerstwa w zakresie polityki spójności. 
cześnie do ogólnych założeń ustrojowych ${ }^{23}$ - jest właśnie konsensualny mechanizm kształtowania wzajemnych relacji.

Przeprowadzone badania wykazały, że sposób zorganizowania działań oparty jest na prawnie ustalonym następstwie. Przyjęta konstrukcja normatywna prowadzenia polityki rozwoju zakłada, że cel publiczny: trwały i zrównoważony rozwój oraz spójność, możliwy jest do osiagnięcia przez łączenie działań w większe ich zespoły tworzące „ciag działań” ${ }^{4}$, które mają charakter wzajemnie uzupełniających się i warunkujących zachowań. Oznacza to, że taki sposób ich zorganizowania stanowi dla ustawodawcy przesłankę skuteczności oraz efektywności działań, do których podejmowania zobowiązane sa wszystkie podmioty władzy wykonawczej. Działania te tworzą sieć powiąań i współzależności publicznoprawnych pomiędzy uczestnikami tych złożonych zespołów czynności, wyznaczanych celem publicznym prowadzenia polityki rozwoju oraz założeniami ustrojowymi sprawowania władzy w państwie.

\section{PUBLICZNOPRAWNE DZIAŁANIA POWIĄZANE}

Fundamentem kształtowania ustawowo określonych prawnych relacji pomiędzy podmiotami prowadzenia polityki rozwoju sa konstytucyjne podstawy ustroju terytorialnego państwa ${ }^{25}$. Decydujący wpływ na charakter wzajemnych stosunków, które tworzą szczególną konstrukcję publicznoprawnych relacji zachodzących pomiędzy podmiotami prowadzenia polityki rozwoju, wynika z ich pozycji ustrojowej. Zasady organizacji i działania struktur władzy publicznej, tryb współpracy ${ }^{26}$ oparty na współdziałaniu hierarchicznie niepodporządkowanych podmiotów władzy wykonawczejej, a także zakres i charakter zadań

${ }^{23}$ Zob. T. Rabska, Działania administracji publicznej w świetle wspótczesnej koncepcji publicznego prawa gospodarczego, w: B. Popowska, K. Kokocińska (red.), op. cit., s. 29.

${ }^{24}$ Zob. A. Chełmoński, Ciag dziatań prawnych w gospodarce państwowej jako przedmiot badań propozycja metodologiczna, Acta Universitatis Wratislaviensis, Prawo XXXVIII, No 163, Wrocław 1972, s. 2-22; T. Kuta, Aspekty prawne dziatań administracji publicznej $w$ organizowaniu ustug, Wrocław 1969; A. Błaś, Proces administrowania jako zorganizowany układ działań administracji publicznej, Acta Univesrsitatis Wratislaviensis, Prawo XXXVI, No 169, Wrocław 1972, s. 83-90; idem, Prawne aspekty działań złożonych administracji państwowej, Acta Universitatis Wratislaviensis, Przegląd Prawa i Administracji VI, No 261, Wrocław 1975, s. 101-110.

${ }_{25}$ Zob. K. Kokocińska, Planowanie rozwoju regionu przez administrację regionalna - decentralizacja?, w: Funkcje wspótczesnej administracji gospodarczej, Poznań 2006; eadem, Udziat jednostek samorzadu terytorialnego $w$ prowadzeniu polityki rozwoju, w: Materialne prawo administracyjne, cz. I, Forum Naukowe, rok XII, nr 4 (22) /2007; eadem, Prawne gwarancje udziatu jednostek samorzadu terytorialnego $w$ prowadzeniu polityki rozwoju (postulowane kierunki zmian koncepcji polityki rozwoju), w: K. Kiczka (red.), Administracja publiczna w Europie małych ojczyzn, Poznań 2009; eadem, Gmina jako podmiot prowadzenia polityki rozwoju, w: L. Kieres (red.), Nowe problemy badawcze $w$ teorii publicznego prawa gospodarczego ( $z$ uwzględnieniem samorzadu terytorialnego), Wrocław 2010.

${ }^{26}$ Szerzej: K. Kokocińska, Wybrane formy prowadzenia polityki rozwoju, w: B. Popowska, K. Kokocińska (red.), op. cit., s. 135-180.

${ }^{27} \mathrm{~K}$. Kokocińska w rozważaniach na temat współdziałania typu konsensualnego podmiotów prowadzenia polityki rozwoju podnosi: „[...] W granicach wyznaczonych przez system prawny, 
oraz niewładcze formy działania tworzą spójną całość. Zbiór tych elementów, $\mathrm{w}$ ujęciu wyznaczonym przez wzajemnie powiązane relacje (nazwany przeze mnie ,prawnym mechanizmem prowadzenia polityki rozwoju”"28), zapewnia zdolność realizacji ustawowo wskazanej powinności publicznej.

Ten sposób wykonywania wspólnych powinności publicznych (tu: prowadzenia polityki rozwoju), oparty na wzajemnie powiąanych działaniach podmiotów władzy publicznej określony został przeze mnie jako „publicznoprawne działania powiązane”. Tak jak wskazałam: „Na to nowe pojęcie prawne składa się łącznie, w ścisłym powiązaniu, szereg elementów. Przede wszystkim działania te podejmowane sa przez podmioty pozostające w szczególnych układach strukturalnych (w strukturach zdecentralizowanej władzy publicznej), dotyczą zadań publicznych realizujących normatywnie określony wspólny cel publiczny, podejmowanych w ustawowo określonych formach i przy zachowaniu określonych prawnie procedur. [...] Podkreślić przy tym należy, że istota "publicznoprawnych działań powiązanych" zasadza się przede wszystkim na wzajemnym stosunku podmiotów podejmujacych te działania oraz charakterze prawnym związków zachodzących pomiędzy nimi, związków o charakterze ustrojowym”29, tworzy bowiem szczególny „ciag działań prawnych”.

Badania w obszarze prowadzenia polityki rozwoju wskazuja, że dla skuteczności działania administracji państwa (administracji rządowej i samorządowej), relacje pomiędzy podmiotami prowadzenia polityki rozwoju (Rada Ministrów a jednostkami samorządu terytorialnego oraz pomiędzy tymi jednostkami), sa ukształtowane przez konstytucyjne podstawy ustroju terytorialnego państwa, a fundamentem organizowania struktury i działania podmiotów prowadzenia polityki rozwoju jest decentralizacja władzy publicznej.

Podejście to determinuje zakres wspólnych spraw, ustawowy nakaz wspólnego celu publicznego (w tym przypadku szczególnie szeroko, systemowo określonego jako „zespół wzajemnie powiązanych działań podejmowanych i realizowanych w celu zapewnienia trwałego i zrównoważonego rozwoju kraju, spójności społeczno-gospodarczej, regionalnej i przestrzennej, podnoszenia konkurencyjności gospodarki oraz tworzenia nowych miejsc pracy w skali krajowej, regionalnej lub lokalnej”), wskazanej normatywnie powinności publicznej wspólnej dla wszystkich podmiotów władzy wykonawczej. Zespół wzajemnie powiązanych działań składający się ze swoistych uzupełniających się i warunkujących elementów strukturalnych i proceduralnych, determinujących stopień współpracy w ramach normatywnej organizacji podmiotów prowadzenia polityki rozwoju, zapewnić ma prawidłowe funkcjonowanie struktur aparatu państwa i osiagnięcie spójności działań (polityki) podmiotów władzy publicznej.

\footnotetext{
w obrębie umownego węzła stosunku publicznoprawnego następuje wyznaczanie relacji publicznoprawnych samodzielnych podmiotów władzy publicznej oraz modelowanie zależności pomiędzy tymi podmiotami. Ma to bezpośredni wpływ na sposób organizacji realizacji zadań publicznych, powodując określone konsekwencje ustrojowe [...] (eadem, Prawny mechanizm..., s. 185).

${ }^{28}$ Ibidem, s. 262 i n.

${ }^{29}$ Ibidem, s. 259 i n.
} 


\section{KONCEPCJA DZIALAŃ POWIĄZANYCH WE WSPÓŁCZESNYCH STOSUNKACH ZARZĄDZANIA}

Normatywna konstrukcja ,zespołu wzajemnie powiązanych działań” przyjęta w ustawie o zasadach prowadzenia polityki rozwoju stanowiła podstawę sformułowania koncepcji „publicznoprawnych działań powiąanych” w oparciu o regulacje ustawy o zasadach prowadzenia polityki rozwoju i dotyczy określonych w tej ustawie stosunków. Nie oznacza to, że nie może mieć ona charakteru uniwersalnego.

Układ podmiotów władzy publicznej, współpraca i powiązanie różnych stosunków moga występować w innych działach funkcjonowania współczesnej administracji publicznej. „Publicznoprawne działania powiąane» wpisuja się w system wieloszczeblowego zarządzania publicznego i partnerstwa rozumianych, jako dzielenie się władzą publiczną pomiędzy poszczególne podmioty publiczne. Stanowią także podstawę kształtowania stosunków pomiędzy sektorem publicznym a sektorem prywatnym"s0.

Przyjęta normatywnie konstrukcja ,zespołu wzajemnie powiązanych działań” (i odpowiadająca jej koncepcja teoretycznoprawna „publicznoprawnych działań powiązanych”) stanowi wyraz tendencji rozwojowych współczesnego systemu administracji publicznej ${ }^{31}$ - wynika z określonego układu stosunków społecznych i gospodarczych, a także politycznych. Podstawę organizowania działań w obszarze „wspólnych spraw”, przy ustawowym nakazie wspólnego osiagania celu publicznego, stanowią ustrojowe zasady sprawowania władzy w państwie oraz gwarantowany konstytucyjnie ustrój terytorialny oparty na decentralizacji władzy publicznej i umacnianiu uprawnień wspólnot samorządowych.

Zmieniające się uwarunkowania społeczne, gospodarcze, a także terytorialne wymagają nowych sposobów organizowania wykonywania funkcji państwa i odpowiedniej organizacji ich działań. Naturalną konsekwencją wspólnej przestrzeni działania, a co za tym idzie - występowania problemów wymagajacych konsensusu przy ich rozwiązywaniu, jest kształtowanie relacji na zasadzie współpracy. Dlatego w działaniach legislacyjnych konieczne jest ciagłe pogłębianie procesów decentralizacji w poszczególnych sferach życia społeczno-gospodarczego, intensyfikowanie demokratycznych form sprawowania

${ }^{30}$ K. Kokocińska, Prawny mechanizm..., s. 268.

${ }^{31} \mathrm{Na}$ temat uwarunkowania kształtowania współczesnej administracji publicznej i przekształceń jej funkcji zob. m.in.: B. Adamiak, Uwagi o współczesnej koncepcji organu administracji publicznej, w: E. Ura (red.), Jednostka, państwo, administracja - nowy wymiar. Międzynarodowa Konferencja Naukowa, Olszanica 23-24 maja 2004 r., Rzeszów 2004; J. Boć, Zatożenia badawcze struktur administracji publicznej, w: J. Zimmermann (red.), Koncepcja systemu prawa administracyjnego. Materiaty konferencyjne (Zakopane 24-27.09.2006 r.), Warszawa-Kraków 2007; T. Rabska, Pytania o stan współczesnej administracji, w: Kierunki rozwoju prawa administracyjnego, Poznań 1999; Z. Niewiadomski, Pojęcie administracji publicznej, w: System prawa administracyjnego, t. 1: Instytucje prawa administracyjnego, red. R. Hauser, Z. Niewiadomski, A. Wróbel, Warszawa 2010, s. 1-60 i wskazywana tam literatura. 
rządów, zwiększenie obszarów współstanowienia i współodpowiedzialności podmiotów władzy wykonawczej na różnych stopniach podziału terytorialnego, a także rozwijanie instrumentów współpracy administracji publicznej (rządowej i samorządowej) oraz wprowadzanie procedury publicznoprawnych działań powiązanych.

dr hab. Katarzyna Kokocinska

Uniwersytet im. Adama Mickiewicza w Poznaniu

katarzyna.kokocinska@amu.edu.pl

\section{DECENTRALISATION AS A POLITICAL REGIME PRINCIPLE UNDERLYING RELATIONSHIPS AMONG DIFFERENT BODIES OF PUBLIC AUTHORITIES}

\section{Sum mary}

This article provides a characteristic of the basic principles underlying organisation of executive power bodies. Their tasks performed in a new sphere of public life defined as 'conducting a development policy' have been discussed. What has been emphasised is the normative approach to this public duty seen as a set of interconnected actions undertaken and implemented with a view of ensuring a stable and sustainable development of the country, social-economic spatial cohesion at the regional level, enhanced competitiveness of the economy and creation of new jobs at a local and regional level as well as nation-wide. Of essential importance for shaping legal relations between organs of public authority, i.e. the Council of Ministers, self-governing regional authorities and local authorities are the constitutional foundations of the territorial regime of the state. What is also emphasised is that the constitutional principle of decentralised public power determines the manner in which development policy is being organised both in terms of its structure and procedural issues. Implementation of the development policy defined in statute as executing a public duty is based on the principles specified in the Act on the Principles of Conducting Development Policy. They constitute a network of mutual relationships among individual bodies holding executive power called 'interconnected public duties' that are determined by a public goal (development policy) and the political regime adopted for the enforcement of authority in a state. 